\title{
Determinants of merger and acquisition activity in Australian cooperative deposit-taking institutions
}

\author{
Andrew C. Worthington ${ }^{*}$ \\ School of Economics and Finance, Queensland University of Technology, GPO Box 2434, Brisbane, QLD 4001, Australia
}

\begin{abstract}
A two-stage procedure is employed to evaluate the determinants of merger and acquisition (M\&A) activity in Australian credit unions over the period 1992/93 to 1994/95. In the first stage, data envelopment analysis is used to calculate technical and scale efficiency indices for a sample of credit unions. The second stage uses a multinomial logit model to relate credit union efficiency scores, along with other managerial, regulatory and financial factors, to the probability of credit unions acquiring or being acquired by another credit union. The results indicate that asset size and quality, management ability, earnings and liquidity are a significant influence on the level of M\&A. One primary influence on credit union acquisitions would appear to be the perceived compatibility in associational bond and membership.
\end{abstract}

Keywords: Mergers and acquisitions, Credit unions, Data envelopment analysis, Technical and scale efficiency.

For most of their history, credit unions have operated within a well-defined, institutionspecific, regulatory sub-sector of the Australian financial system. However, in the period following deregulation Australian credit unions were forced to adapt to a newly competitive environment. The most discernible response has been a dramatic increase in merger and acquisition (M\&A) activity. In point of fact, competitive pressures for consolidation are not confined to Australia and are relatively commonplace for financial mutuals and other small deposit-taking institutions throughout the world. In the United States restrictions on expansion through branches and acquisitions across state lines have been progressively dismantled through the weakening of the Glass-Stegall Act and the recent passage of the Riegle-Neal Banking Act (Cyree et al., 2000). These and other competitive pressures have seen a dramatic increase in interstate and intrastate acquisitions among credit unions and S\&Ls (Shaffer, 1993; Grabowski et al., 1995) and a renewed emphasis on the examination of financial and productive performance in financial mutuals (Cebenoyan et al., 1993; Grabowski et al., 1993; Fried et al., 1996). In the United Kingdom building societies are the major financial mutuals and are likewise the subject of increasing empirical attention in this regard [see, for example, Piesse and Townsend (1995), Drake and Weyman-Jones (1996) and 
Thompson (1997)]. The close correspondence of the role and competitive environment of financial mutuals in Australia, the United States and the United Kingdom, amongst others, provides a compelling rationale for the examination of M\&A activity in alternative institutional milieus.

However, examination of existing empirical evidence on the managerial, regulatory and financial determinants of financial institution mergers suggests that the motives for mergers in cooperative deposit-taking institutions vary substantially from those found in, say, commercial banks. One aspect of this process is the major behavioural differences between the private ownership claims found in mutual organisations and their joint stock equivalents. Thompson (1997, p. 38), for example, has argued, “this is curious since, at least in the context of an Anglo-American type of corporate governance system, it is the threat of a hostile takeover which represents the ultimate disciplinary sanction for managers who depart from shareholder value maximisation. By contrast, most countries' mutual sectors are so constituted that hostile acquisition is impossible”. Accordingly, there is the suggestion that structural change in cooperative financial services is essentially restricted to 'friendly' mergers, and that there is a large degree of acquiescence by regulatory authorities in this matter (Thompson, 1997).

Likewise, decision rules in cooperative enterprises primarily rest on democratic principles, rather than ownership concentration. Traditionally, this has been used to suggest that the appropriate behavioural assumption in cooperative institutions is the maximisation of member services rather than profits. However it has also been suggested by Garden and Ralston (1999), amongst others, that the process of deregulation, and the increased competition from the entry of new market participants (e.g. mortgage specialists, insurance companies, etc.), has meant that management and regulators have increasingly shaped the objectives of credit unions towards a more commercial orientation. In this manner, any pre-existing ideological imperatives found in credit unions have been constrained by the need to function in a highly competitive financial market.

Accordingly, any analysis of the motives for merger activity in cooperative deposit-taking institutions is likely to involve the complex interaction of a large number of factors. Furthermore, it is likely that these motives have changed substantially during the recent program of financial reform. On one hand, the behavioural objectives of cooperative deposittaking institutions, including credit unions, are relatively complex, and should take account of

\footnotetext{
* Tel.: +61-7-3864-2658; fax: +61-7-3864-1500. E-mail address: a.worthington@qut.edu.au
} 
the overriding objective of maximising member services. On the other, the process of deregulation in the Australian financial services industry has emphasised the role of management and regulators, with a corresponding emphasis on improving efficiency and financial viability. A careful analysis of these divergent forces should therefore add to our knowledge about the factors determining the pattern of structural change in Australia financial services, and provide at least some idea of the effectiveness of recent microeconomic reform, especially in regard to some of the smaller deposit-taking institutions.

In this paper an attempt is made to examine the determinants of M\&A activity in Australian credit unions. The paper itself is divided into four main sections. The first section focuses on the characteristics of credit unions in Australia, especially those that are likely to impact upon decisions concerning merger and acquisition activity. The second section deals with the specification of those variables posited to influence the recent pattern of M\&A. The third section presents the empirical results of the analysis. The paper ends with some brief concluding remarks in the final section.

\section{Merger and acquisition in the cooperative financial sector}

Credit unions are generally presented as maintaining an objective and culture unlike that of any other Australian financial institution. Similarly, and despite the recent program of microeconomic reform, credit unions and other cooperative societies operating in Australia receive differing treatment under the regulatory system to all other financial institutions, including commercial banks. These impact upon the process of merger and acquisition in the credit union industry, and correspondingly on empirical efforts to model this process. Several salient points are noted.

The first key consideration is that credit unions in Australia operate on a cooperative basis, principally by borrowing from and providing finance to their members. And in general, these institutions have maintained the key principle of 'mutuality': implying 'one member, one vote', regardless of the size of the individual member's deposits or loans (Garden and Ralston, 1999). When combined with the fact that a credit union cannot acquire shares in another, the suggestion is that a merger of credit unions must be agreed to by both parties; a hostile take-over of a sound credit union therefore being difficult, if not impossible, to achieve (Brown et al., 1999). Likewise, in Australia liquidation of credit unions has been extremely rare, and it is widely understood that the exit of credit union in financial distress is 
likely to occur through merger rather than liquidation. In most instances, and well before any question of insolvency, regulators have evaluated possible partners for merger and facilitated the exit of an unsound credit union.

The second key consideration is that a credit union's overriding objective is generally accepted to be maximisation of member benefits rather than profit-maximisation. However, there is evidence that the objectives of credit unions have increasingly been shaped by management towards a more conventional profit-orientation. The most obvious reason is that decisions by management with respect to member services are made in the context of a highly competitive financial sector. This has meant that long-standing practices in the commercial banking sector have been recently adopted in cooperative deposit-taking institutions. One example is the widespread adoption of a 'user-pays' system of charges with respect to deposit accounts. Another reason for the erosion of the member-services orientation is associated with the strengthening asset growth rate for credit unions. There is the suggestion that the rapid growth of credit unions has heightened the power of management at the expense of member control. For example, O’Brien (1993) has argued that commercial interests in credit unions have progressively dominated any earlier philosophical or social commitments.

The third key consideration is that the regulatory environment within which Australian cooperative deposit-taking institutions operate has also reoriented credit unions towards profit-maximisation. Since the introduction of the Australian Financial Institutions Act 1992, credit unions have been subject to a risk-weighted capital adequacy requirement of eight percent, equivalent to that imposed on banks. They are also required to hold seven percent of their liabilities as prime liquid assets, and a further six percent as liquid funds under an operational liquidity requirement. The argument here is that since capital is usually held in the form of retained earnings, the only way credit unions can build up sufficient reserves to allow asset growth is through the accumulation of operating surpluses. Davis (1994, p. 44) has argued that this process will necessarily focus management attention upon financial targets not necessarily consistent with the credit union's goals as a cooperative. More importantly, it has been suggested that the stringent portfolio constraints on liquidity, capital and lending in credit unions (including provisions that more than sixty percent of total assets are loans to members), highlight merger as a means of increasing capital base and improving efficiency.

The final key consideration is that in spite of the erosion of the traditional objectives of credit unions, there is still an emphasis on the common bond or affinity that defines membership of individual credit unions. For example, a common bond technically restricts 
membership of individual credit unions in Australia to three categories; namely, industrial (employee) groups; community (geographic) groups; and parish (religious) groups. This common bond is argued to be an important reason for the industry's success to date, but it is also a potential limitation on future growth. On one hand, it encourages member loyalty to the institution (which in some instances may override the desire for the cheapest alternative form of banking), while on the other it may restrict the extent of growth by an excessively restricted potential customer base (Garden and Ralston, 1997). Though the process of merger among Australian credit unions has seen a considerable weakening of these bonds, it also suggests that more immediate concerns in finding a merger partner may be consideration of consistency of purpose and geographic location as a means of preventing erosion of member loyalty.

Accordingly, three possible characterisations of the merger process are likely to be found when modelling mergers in Australian cooperative deposit-taking institutions. The first is that the merger process reflects the reorientation of credit unions services towards profitmaximisation, and is therefore predominately driven by managerial objectives. Thompson (1997, p. 39) has argued that this mechanism is comparable to that provided by the market for corporate control in the joint stock sector, which "works to eliminate underperforming mutuals and transfer their assets to other societies within the sector”. The second characterisation is that the merger process reflects direct intervention by regulators to promote efficiency and stability within the financial system. Moreover, regulatory constraints placed upon credit unions may highlight mergers as a means of increasing capital base and operative efficiency in the increasingly competitive financial services industry. The final characterisation is that notwithstanding the commercial and regulatory imperative discussed earlier, the notion of a bond of association may exert a strong influence on merger activity through both commercial and ideological concerns.

\section{Empirical methodology}

The data used in this study consists of annual observations of all Australian credit unions. All data is sourced from the Australian Prudential Regulation Authority (APRA) and its immediate predecessor the Australian Financial Institutions Commission (AFIC). The time period selected is the three financial years 1992/93 to 1994/95. The total number of credit unions in operation and the number of merging and acquiring credit unions vary over the 
sample period. Of the 323 credit unions in operation in 1992/93, 19 institutions were 'acquired' in 1993/94 with 15 credit unions 'acquiring' one other credit union, and 2 credit unions acquiring more than one credit union in the same year. Of the 304 credit unions remaining in operation in 1993/93, 16 credit unions subsequently merged with 14 acquiring credit unions in 1994/95. Of these, two credit unions were acquired by the same acquiring credit union and one credit union merged with a building society. Finally, 9 credit unions were acquired by 9 credit unions in 1995/96 from a total 1994/95 population of 290 credit unions. A more extensive set of time-series data would, of course, be more valuable. Unfortunately, a national framework for the prudential supervision of State-based non-bank deposit-taking institutions (along with the requisite database) was only established with the creation of AFIC in July 1992.

A pooled time-series, cross-sectional multinomial logit model with an assumption of common effects is used to analyse the factors that influence M\&A activity in cooperative deposit-taking institutions. In any given year, a credit union has three possible (unordered) outcomes: (i) be acquired by another credit union; (ii) acquire another credit union; or (iii) maintain the status quo. Hence the following model is estimated:

$$
\operatorname{Prob}\left(Y_{i}=j\right)=\frac{e^{\beta_{j}^{\prime} x_{i}}}{\sum_{j=1}^{J} e^{\beta_{j}^{\prime} x_{i}}}, j=0,1, \ldots, J
$$

where the probability of the occurrence of the dependent variable, $j$ (indicating each credit union's M\&A status), is thought to depend on a set of financial, managerial and regulatory factors, $x$, and $\beta$ is a set of parameters to be estimated. Of course, several alternative models could be equally well used. For example, Cyree et al. (2000) use a two-stage logistic regression approach to estimate the probability of a particular growth strategy, contingent on the choice of the bank to grow.

Descriptive statistics for the variables contained in the explanatory vector $x$ for each of the three financial years are presented in Table 1. These variables represent various aspects of firm performance and are structured in accordance with a CAMEL (capital structure, asset quality, management ability, earnings and liquidity) regulatory classification system. The variables used to represent various aspects of credit union performance are comparable to those employed by Thompson (1997) in an analysis of mergers in UK building societies. 
The first variable in Table 1 relates to the role of capital structure in determining the likelihood of merger or acquisition in credit unions. Capital is of particular concern in depository financial institutions of this type because of their low net worth and highly leveraged nature, which creates a potential for failure should there be a sudden withdrawal of deposits. The measure of capital within each institution is defined as the ratio of reserves (including permanent share capital, asset revaluations and retained earnings) to total assets $(C A P)$. All other things being equal, an acquired (acquiring) credit union should have a relatively lower (higher) level of capital (Berger et al., 1993; 1999). A negative coefficient is hypothesised for acquired credit unions and a positive coefficient for acquiring credit unions.

The second variable relates to the asset management activities of each credit union. Asset quality measures are concerned with assessing the default or credit risk of the loan portfolio, as well as the allocation of the asset portfolio between liquid investments and loans. One measure used is the ratio of provision for doubtful debts expense to total loans (PRD). The ex ante sign on this coefficient is thought to be positive (negative) for acquired (acquiring) credit unions, reflecting in part the extent of asset diversification and the impact of asset risk on merger activity.

The next two variables included in the regression relate to management ability vis-à-vis technical efficiency and the scale of operations in relation to scale efficiency. The method used to measure efficiency in these credit unions is based upon data envelopment analysis (DEA), a mathematical programming approach to frontier estimation pioneered in Charnes et al. (1978) and extended in Banker et al., (1984). Suitable introductions to DEA may be found in Coelli et al. (1997) and Cooper et al. (2000). Measuring efficiency in this manner is consistent with both the recent literature associated with the efficiency analysis of deposittaking institutions in general, including Elyasiani et al., (1994), Favero and Papi (1995), Miller and Noulas (1996), and with a large number of past empirical approaches to efficiency measurement in non-bank financial institutions, notably Piesse and Townsend (1995), Drake and Weyman-Jones (1996) and Worthington (1998; 1999; 2000). Berger and Humphrey (1997) provide a comprehensive survey of the various approaches to efficiency measurement in financial institutions.

In brief, the advantages and disadvantages of the DEA approach to efficiency measurement are as follows. To start with, one obvious problem with DEA is that in contrast to the econometric approaches to efficiency measurement it is both nonparametric and nonstochastic. Thus, no accommodation is made for the types of bias resulting from 
environmental heterogeneity, external shocks, measurement error, and omitted variables. Consequently, the entire deviation from the frontier is assessed as being the result of inefficiency. This may lead to either an under or over-statement of the level of inefficiency.

However, there a number of benefits implicit in the mathematical programming approach that makes it attractive on a theoretical level. First, given its nonparametric basis it is relatively easy to alter the specification of inputs and outputs and thereby the formulation of the production correspondence relating inputs to outputs. Thus, in cases where the usual axioms of production activity breakdown (i.e. profit maximisation) then the programming approach may offer useful insights into the efficiency of these types of industries. This is especially the case with mutual financial institutions. Second, when using the alternative econometric approach considerable structure is imposed upon the data from both stringent parametric form and distributional assumptions regarding both inefficiency and, in the case of stochastic frontiers, statistical noise. These considerations, and the natural emphasis of DEA on the notion of 'best-practice' performance, make it an attractive method of measuring efficiency in credit unions.

The computational procedure used to implement the DEA approach to efficiency measurement is presented briefly as follows. Consider $N$ credit unions each producing $M$ different outputs using $K$ different inputs in a particular time period. The $K \times N$ input matrix, $X$, and the $M \times N$ output matrix, $Y$, represent the data of all $N$ credit unions, while for the individual credit union these are represented by the vectors $x_{i}$ and $y_{i}$. The efficiency of each credit union can be determined from the solution to the following linear program:

$$
\begin{aligned}
\min _{\theta, \lambda} \theta \\
\text { s.t. }-\mathrm{y}_{\mathrm{i}}+Y \lambda \geq 0 \\
\theta x_{i}-X \lambda \geq 0 \\
\lambda \geq 0
\end{aligned}
$$

where $y_{i}$ is the vector of outputs produced by the ith credit union, $x_{i}$ is the vector of inputs used by the ith credit union, $i$ runs from 1 to $N$, and $j$ equals $1,2, \ldots, N, \theta$ is a scalar and $\lambda$ is a $N \times 1$ vector of constants. The value of $\theta$ will be the technical efficiency score for a particular credit union. It will satisfy $\theta \leq 1$, with a value of 1 indicating a point on the frontier, and hence a technically efficient credit union. The value of $\theta \leq 1$ identifies the amount of any inefficiency that may be present. 
Table 1

Explanatory variable descriptive statistics

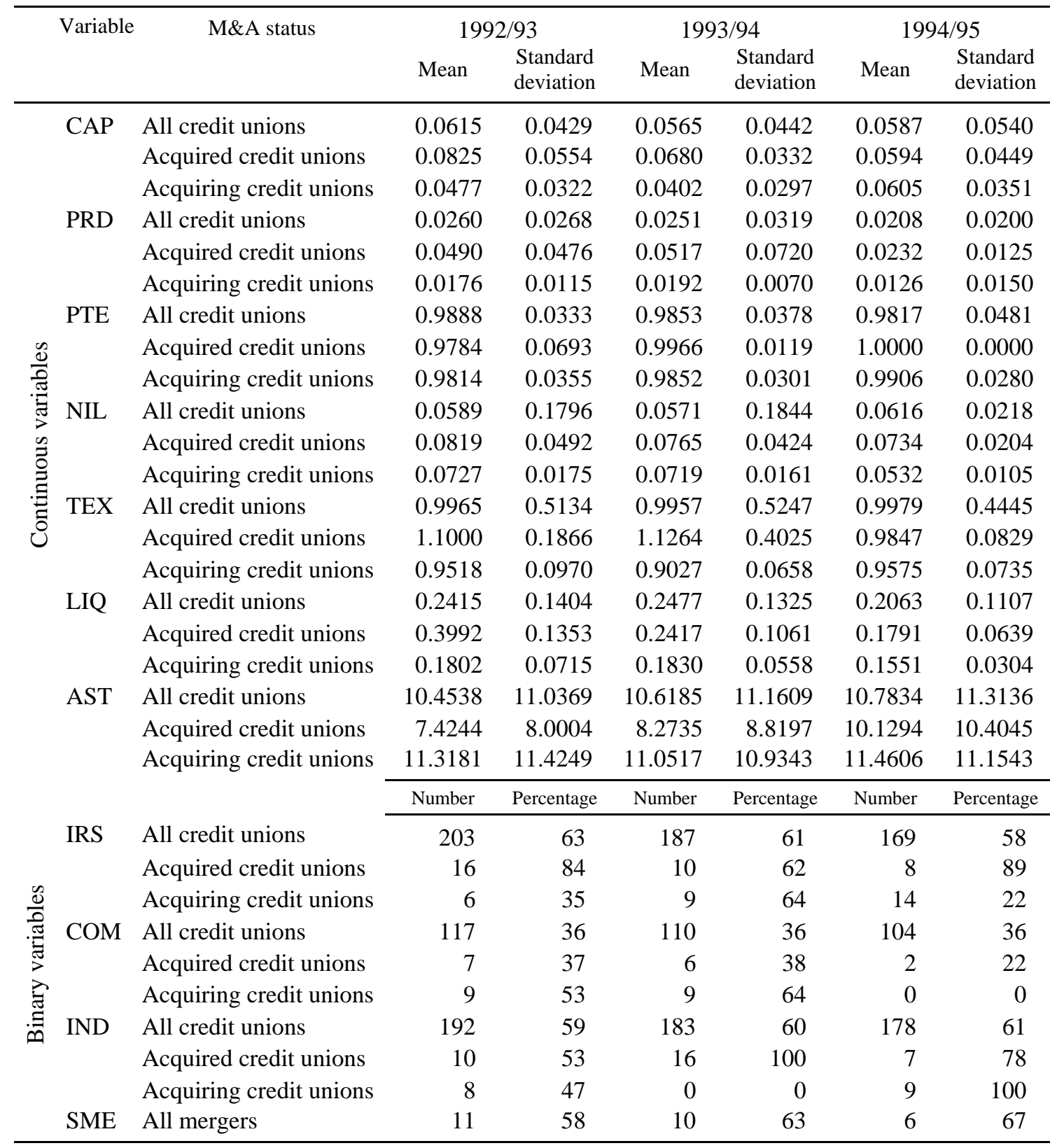

Notes: CAP is the ratio of capital reserves to total assets; PRD is the ratio of the provision for doubtful debts to total loans; PTE is an index measure of pure technical efficiency; NIL is the ratio of net interest income to total loans; TEX is the ratio of total expenses to total income; LIQ is the ratio of prime liquid assets to total assets; AST is the $\log$ of total assets; IRS is one if the credit union has increasing returns-to-scale and zero otherwise; COM is one if the credit union is community-based and zero otherwise; IND is one if the credit is industrial-based and zero otherwise; SME is one if both the acquired and acquiring credit union are either community or industrial-based.

In this program, emphasis is placed on the equiproportionate reduction of inputs. An input orientation is adopted since it is assumed that capital adequacy and liquidity requirements are likely to restrict the level of output in any time period. Hence, a suitable behavioural objective for these institutions would be that of input minimisation, rather than output maximisation. The input measures thus provided can then detect failures to minimise inputs resulting from 
discretionary power and incomplete monitoring, and thereby provide an indication of possible gains from exploiting technical efficiencies. Other efficiency studies that employ an inputorientated approach include Worthington's (1998) analysis of Australian credit unions and Drake and Weyman-Jones' (1996) study of UK building societies. In addition, profit maximisation is not assumed. This follows the majority of empirical work in the area of financial mutual efficiency measurement [see, for instance, Piesse and Townsend (1995), Fried et al. (1996), Thompson (1997), Worthington (1998; 1999)]. In defence, Fried et al. (1993, p. 253) argue, "since credit unions are owned and operated by members, the objectives of credit unions can be thought of as maximising services provided to members. This immediately suggests that profit maximisation is not an appropriate objective”. Nonetheless, an emerging literature has begun to see credit unions as 'conditional' profit maximisers where profits are maximised conditional on prices in order to, amongst other things, subsidise loan and deposit rates. For example, Westley and Shaffer (1999) adopted a profit function approach for a study of Latin American credit unions and used a survey to gain the requisite data on wages and loan/deposit rates. Unfortunately, information of this type for Australian credit unions is not available.

The model specified in (2) also has an assumption of constant returns-to-scale and is only appropriate where all credit unions are operating at an optimal scale. Where this assumption does not hold, scale effects will confound the measures of technical efficiency. Generally, regulatory, geographical and institutional constraints imply that most credit unions are not operating at an optimal scale. Following Banker et al. (1984) the linear programming problem can be modified to account for variable returns-to-scale (that is, measures of technical efficiency without scale efficiency effects) by adding the convexity constraint $N 1^{\prime} \lambda=1$ to (2). The measure of technical efficiency obtained without the convexity constraint (that is, under an assumption of constant returns-to-scale) is referred to as overall technical efficiency. The measure obtained including the convexity constraint (that is, assuming variable returns-to-scale) is known as pure technical efficiency (PTE). Dividing overall technical efficiency by pure technical efficiency yields a measure of scale efficiency. A single variable is subsequently defined for the multinomial logit analysis in (1). This is an index measure of pure technical efficiency (PTE). All other things being equal, an acquired (acquiring) credit union is expected to be relatively less (more) pure technically efficient than an acquiring (acquired) credit union. Put differently, managerial ability is thought to be higher in acquiring credit 
unions than acquired credit unions. A negative (positive) coefficient is expected for acquired (acquiring) credit unions.

Table 2

Data envelopment analysis (DEA) input and output descriptive statistics

\begin{tabular}{|c|c|c|c|c|c|c|c|}
\hline \multirow[t]{2}{*}{ Variable } & \multirow[t]{2}{*}{ M\&A status } & \multicolumn{2}{|c|}{ 1992/93 } & \multicolumn{2}{|c|}{$1993 / 94$} & \multicolumn{2}{|c|}{$1994 / 95$} \\
\hline & & Mean & $\begin{array}{l}\text { Standard } \\
\text { deviation }\end{array}$ & Mean & $\begin{array}{l}\text { Standard } \\
\text { deviation }\end{array}$ & Mean & $\begin{array}{l}\text { Standard } \\
\text { deviation }\end{array}$ \\
\hline \multirow[t]{3}{*}{ PHY } & All credit unions & 824.42 & 2088.68 & 887.67 & 2112.55 & 997.01 & 2270.81 \\
\hline & Acquired credit unions & 12.88 & 23.17 & 90.70 & 321.69 & 614.08 & 945.45 \\
\hline & Acquiring credit unions & 1685.08 & 1715.84 & 2168.52 & 3609.81 & 712.12 & 796.17 \\
\hline \multirow[t]{3}{*}{ AC } & All credit unions & 13550.45 & 29095.58 & 16148.56 & 32030.61 & 17378.31 & 34476.35 \\
\hline & Acquired credit unions & 685.00 & 1032.84 & 1408.10 & 2142.07 & 9289.81 & 13879.94 \\
\hline & Acquiring credit unions & 31640.26 & 40380.96 & 24059.83 & 20736.58 & 29457.93 & 20813.49 \\
\hline \multirow[t]{3}{*}{ NW } & All credit unions & 2111.49 & 7114.59 & 2300.77 & 8789.68 & 2170.96 & 8689.85 \\
\hline & Acquired credit unions & 145.75 & 304.40 & 314.57 & 1039.10 & 959.14 & 2178.23 \\
\hline & Acquiring credit unions & 4160.01 & 6717.32 & 1459.46 & 3068.33 & 3868.41 & 3717.92 \\
\hline \multirow[t]{3}{*}{ FT } & All credit unions & 14881.87 & 27589.93 & 17403.78 & 31099.00 & 22486.82 & 39835.27 \\
\hline & Acquired credit unions & 640.67 & 1602.78 & 1768.19 & 3494.32 & 11017.66 & 12999.39 \\
\hline & Acquiring credit unions & 36454.67 & 40324.14 & 29383.77 & 29789.63 & 49380.80 & 40150.59 \\
\hline \multirow[t]{3}{*}{ IX } & All credit unions & 1631.51 & 2966.24 & 1539.83 & 2701.62 & 1995.67 & 3573.69 \\
\hline & Acquired credit unions & 84.98 & 148.81 & 154.09 & 263.20 & 891.91 & 1075.39 \\
\hline & Acquiring credit unions & 4007.18 & 4611.76 & 2400.22 & 2142.32 & 3872.23 & 2886.92 \\
\hline \multirow[t]{3}{*}{ NIX } & All credit unions & 1556.77 & 2756.29 & 1768.46 & 3041.34 & 2014.57 & 3292.60 \\
\hline & Acquired credit unions & 89.60 & 156.28 & 223.76 & 424.88 & 1378.09 & 1897.30 \\
\hline & Acquiring credit unions & 4192.03 & 4859.64 & 2811.69 & 2301.24 & 4244.06 & 3584.54 \\
\hline \multirow[t]{3}{*}{ PL } & All credit unions & 13539.78 & 24446.06 & 14435.03 & 25280.52 & 16354.47 & 28015.65 \\
\hline & Acquired credit unions & 801.81 & 1457.94 & 1911.65 & 2688.43 & 8451.97 & 9708.99 \\
\hline & Acquiring credit unions & 34779.06 & 41596.11 & 24124.69 & 19657.94 & 36355.60 & 35224.80 \\
\hline \multirow[t]{3}{*}{ CL } & All credit unions & 560.02 & 1933.90 & 908.03 & 2487.67 & 1490.82 & 3938.48 \\
\hline & Acquired credit unions & 128.39 & 517.17 & 39.45 & 157.78 & 439.71 & 930.90 \\
\hline & Acquiring credit unions & 840.97 & 1767.85 & 535.85 & 800.22 & 1433.98 & 2281.25 \\
\hline \multirow[t]{3}{*}{ RL } & All credit unions & 10718.41 & 22150.98 & 14072.17 & 27622.94 & 18247.08 & 36190.70 \\
\hline & Acquired credit unions & 171.18 & 744.11 & 893.13 & 2532.16 & 10358.97 & 16445.03 \\
\hline & Acquiring credit unions & 23951.37 & 25454.27 & 21538.69 & 24757.60 & 36082.95 & 27647.70 \\
\hline \multirow[t]{3}{*}{ INV } & All credit unions & 6863.27 & 13295.93 & 8266.89 & 14969.96 & 8059.45 & 13957.16 \\
\hline & Acquired credit unions & 503.51 & 620.53 & 856.46 & 1318.93 & 4159.70 & 5232.37 \\
\hline & Acquiring credit unions & 15747.97 & 17389.71 & 11075.25 & 9016.69 & 16116.54 & 12195.32 \\
\hline \multirow[t]{3}{*}{ IY } & All credit unions & 3295.55 & 5801.45 & 3402.46 & 5795.12 & 4011.00 & 6777.10 \\
\hline & Acquired credit unions & 167.77 & 302.38 & 347.13 & 586.49 & 2207.67 & 2754.01 \\
\hline & Acquiring credit unions & 8355.67 & 9919.52 & 5533.52 & 4804.37 & 8211.82 & 6539.91 \\
\hline \multirow[t]{3}{*}{ NIY } & All credit unions & 258.56 & 646.35 & 325.99 & 787.21 & 392.39 & 912.50 \\
\hline & Acquired credit unions & 6.85 & 14.03 & 34.14 & 75.90 & 193.58 & 302.82 \\
\hline & Acquiring credit unions & 584.48 & 604.25 & 431.38 & 601.36 & 633.14 & 675.95 \\
\hline
\end{tabular}

Notes: PHY is physical capital; AC is at-call deposits; NW is notice-of-withdrawal deposits; FT is fixed term deposits; IX is interest expenses; NIX is non-interest expenses; PL is personal loans; CL is commercial loans; RL is residential loans; INV is investments; IY is interest income; NIY is non-interest income.

One shortcoming of the measure of scale efficiency defined is that its value does not indicate whether the credit union is operating in an area of increasing or decreasing returns- 
to-scale. This may be determined by imposing non-increasing returns-to-scale in (2) by replacing the $N 1^{\prime} \lambda=1$ restraint with $N 1^{\prime} \lambda \leq 1$. If the technical efficiency score under an assumption of non-increasing returns-to-scale is equal to the score obtained under variable returns-to-scale then decreasing returns to scale apply. If they are unequal then increasing returns-to-scale exist for that credit union. The fourth variable defined is a dummy variable indicating the presence of increasing returns-to-scale (IRS). In the short-term, scale may be beyond the control of managers, however it is expected that credit unions operating at a smaller than optimal scale may be acquired.

The inputs and outputs employed in the DEA approach are detailed in Table 2 (in thousands of Australian dollars), and follow the intermediation approach to modelling financial institution behaviour. In this approach credit unions combine physical capital (PHY), at call deposits $(A C)$, notice-of-withdrawal deposits $(N W)$ and fixed term deposits $(F T)$, along with interest $(I X)$ and non-interest expenses $(N I X)$, to produce personal loans $(P L)$, commercial loans $(C L)$ residential loans $(R L)$, investments (INV), interest $(I Y)$ and noninterest income $(N I Y)$. In terms of specific studies, the approach is most consistent with the value-added intermediation approach used by Berg et al. (1993), Favero and Papi (1995) and Fried et al. (1996).

The simple descriptive statistics in Table 2 already highlight some interesting differences between acquiring and acquired credit unions and credit unions as a whole. Turning first to acquired credit unions, in each of the three years one-tailed $t$-tests for equality of means (assuming unequal variances) reject the null hypothesis of equality at the .05 level for each of the twelve variables. These tests then indicate that the average dollar value of physical capital, deposits and loans (across various categories), investments and interest and non-interest expenses and income in acquired credit unions is significantly less than that across credit unions as a whole. Identical one-tailed t-tests are conducted for acquiring credit unions. In this instance, one-tailed $t$-tests for equality of means (assuming unequal variances) reject the null hypothesis of equality at the .05 level for all variables in all years with the exception of NW and $C L$ in 1992/93, RL, INV, IY and NIY in 1993/94 and PHY, NW, PL, CL and NIY in 1994/95. When compared to credit unions as a whole, acquired credit unions have lower mean values across all balance sheet and profit and loss items, while acquiring credit unions generally have higher mean values, though some exceptions are noted.

The next two explanatory variables in Table 1 relate to credit union profitability; namely, the ratio of net interest income to total loans (NIL) and the ratio of total expense to total 
income (TEX). The second measure is particularly pertinent in that it indicates the operational risk of the institution, that is, the possibility that the costs of operating the institution will exceed its revenues, thereby depleting equity capital. A negative relationship is thought to exist between profitability and acquired credit unions and a positive relationship for acquiring credit unions.

The sixth variable is a measure of liquidity, defined as the ratio of prime liquid assets to total assets (LIQ). Insufficient liquidity to meet demand for deposit withdrawals is identified as a key source of depository financial institution risk, and thereby the likelihood that merger activity will be used as a means of managing such risk. A negative (positive) coefficient is thought to exist ex ante for acquired (acquiring) institutions. Lastly, a variable indicating the total assets (AST) of each credit union (in logs) is also included. Abundant evidence already exists that a significant determinant of M\&A activity in financial institutions is size. A positive (negative) coefficient is hypothesised for acquiring (acquired) credit unions.

In addition to these performance-related variables, several qualitative variables relating to the associational bond under which each credit union exists are also included. All other things being equal, a community-based credit union (COM) will have a more diversified membership than an industrial-based one (IND). The usual implication is that the prospects for attaining an efficient scale of operations are higher for community-based credit unions. The ex ante sign on the dummy variable is thought to indicate that community-based credit unions have a higher probability of acquiring, while industrial-based credit unions (especially in vocational areas with a declining workforce) are thought more likely to be acquired. Finally, a dummy variable indicating whether the acquiring and acquired credit union have a common bond is included; that is, both the acquiring and acquired institution is either community or industrial-based (SME). It is important to note that regulatory pressures to maintain a homogeneous membership have been progressively relaxed and that similarity in the membership of acquired and acquiring credit unions is more likely to reflect management's opinion on the compatibility of membership rather than any regulatory imperative. It is posited that mergers where compatible memberships exist are far more likely. A positive coefficient is postulated.

\section{Empirical results}


In the previous section, we formulated models of the determinants of merger and acquisition activity in Australian credit unions over the period 1992/93 to 1994/95. Included among the other measures of firm performance in Table 1 are descriptive statistics of the DEA measures of pure technical and scale efficiency constructed on the basis of the inputs and outputs specified in Table 2. In general, it appears that the pure technical and scale efficiency of acquired and acquiring credit unions varies from the population of credit unions. For example, average pure technical efficiency (PTE) is generally higher in acquiring credit unions, whereas that for acquired credit unions is usually lower. In terms of pure technical efficiency in 1992/93 the average Australian credit union could - and solely on the basis of observable best-practice - become efficient by reducing inputs to 98.8 percent of their current level, while acquired and acquiring credit unions are 97.8 and 98.1 percent pure technically efficient respectively. In comparable studies of Australian credit unions, Brown et al. (1999) and Worthington (1998) found technical efficiencies of 79 and 88 percent respectively. The measure of increasing returns-to-scale (IRS) for 1992/93 in Table 1 also indicates variation between acquired and acquiring credit unions with 84 percent of acquired credit unions operating at a smaller than optimal scale and only 35 percent of acquiring credit unions.

However, while these results are broadly consistent with similar studies of credit unions and other thrifts, variance in sample and empirical methodology preclude valid comparison. In particular, an important feature of DEA is that as the number of inputs and outputs are increased, more and more individual credit unions serve to define the frontier, thereby increasing the average level of efficiency. For example, in an earlier study of Australian credit unions Worthington (1998) employed several alternative specifications with varying numbers of inputs and outputs. The indexes of pure technical efficiency in that study averaged 84 percent with two outputs, 93 percent with three outputs and 98 percent with four outputs.

The estimated coefficients for the multinomial logit regressions themselves are presented in Table 3. Also included in Table 3 are statistics for joint hypothesis and likelihood ratio tests. The results of a prediction success table based upon these estimates are found in Table 4. With the multinomial logit formulation used, $J$ - 1 sets of estimated coefficients are obtained, in this case for the acquiring and acquired credit unions. Credit unions that neither acquired nor were acquired provide the base or reference category. Thus, the estimated coefficients for acquiring and acquired credit unions are relative to credit unions that maintained the status quo, i.e. non-acquiring and non-acquired credit unions. Two separate models are estimated. The estimated coefficients and standard errors employing the entire set 
of managerial and financial factors are shown in Table 3 columns 1 to 4 . In order to refine the overall specification, LR tests were used to test the difference between the full model and a reduced model formed by omitting each effect in turn from the full model. The reduced model is presented in columns 5 to 8 of Table 3.

Table 3

Determinants of M\&A status

\begin{tabular}{|c|c|c|c|c|c|c|c|c|}
\hline \multirow[t]{3}{*}{ Variable } & \multicolumn{4}{|c|}{ Full model } & \multicolumn{4}{|c|}{ Reduced model } \\
\hline & \multicolumn{2}{|c|}{ Acquiring credit unions } & \multicolumn{2}{|c|}{ Acquired credit unions } & \multicolumn{2}{|c|}{ Acquiring credit unions } & \multicolumn{2}{|c|}{ Acquired credit unions } \\
\hline & $\begin{array}{l}\text { Estimated } \\
\text { coefficient }\end{array}$ & $\begin{array}{c}\text { Standard } \\
\text { error }\end{array}$ & $\begin{array}{l}\text { Estimated } \\
\text { coefficient }\end{array}$ & $\begin{array}{c}\text { Standard } \\
\text { error }\end{array}$ & $\begin{array}{c}\text { Estimated } \\
\text { coefficient }\end{array}$ & $\begin{array}{c}\text { Standard } \\
\text { error }\end{array}$ & $\begin{array}{c}\text { Estimated } \\
\text { coefficient }\end{array}$ & $\begin{array}{c}\text { Standard } \\
\text { error }\end{array}$ \\
\hline CONS. & 9.215 & 258.330 & 12.752 & 12.834 & 2.510 & 11.880 & 14.587 & 12.352 \\
\hline CAP & 10.362 & 8.158 & -0.127 & 4.658 & 11.696 & 7.782 & -0.388 & 3.675 \\
\hline PRD & -0.981 & 14.152 & -13.224 & 8.747 & 3.206 & 13.608 & $-13.165^{*}$ & 7.328 \\
\hline PTE & $3.603^{* *}$ & 1.840 & 15.416 & 12.499 & $3.435^{* *}$ & 1.728 & 13.946 & 12.063 \\
\hline IRS & 1.659 & 2.144 & -0.141 & 0.608 & 1.609 & 1.954 & -0.160 & 0.602 \\
\hline NIL & $9.850^{*}$ & 5.261 & 8.573 & 7.428 & $10.863^{* *}$ & 4.124 & 8.158 & 6.839 \\
\hline TEX & 1.285 & 1.245 & -0.002 & 0.498 & & & & \\
\hline LIQ & 1.983 & 3.947 & $-3.543^{*}$ & 1.947 & 1.201 & 3.788 & $-3.481^{* *}$ & 1.597 \\
\hline AST & $0.730^{* * *}$ & 0.252 & $-0.598^{* * *}$ & 0.148 & $0.729^{* * *}$ & 0.245 & $-0.611^{* * *}$ & 0.143 \\
\hline COM & -8.122 & 258.050 & 0.221 & 0.835 & & & & \\
\hline IND & -7.440 & 258.050 & 0.121 & 0.814 & & & & \\
\hline SME & $24.470^{* * *}$ & 0.860 & $24.297^{* * *}$ & 0.001 & $24.328^{* * *}$ & 0.835 & $24.219^{* * *}$ & 0.000 \\
\hline
\end{tabular}

Notes: CAP is the ratio of capital reserves to total assets; PRD is the ratio of the provision for doubtful debts to total loans; PTE is an index measure of pure technical efficiency; IRS is one if the credit union has increasing returns-to-scale and zero otherwise; NIL is the ratio of net interest income to total loans; TEX is the ratio of total expenses to total income; LIQ is the ratio of prime liquid assets to total assets; AST is the $\log$ of total assets; COM is one if the credit union is community-based and zero otherwise; IND is one if the credit is industrial-based and zero otherwise; SME is one if both the acquired and acquiring credit union are either community or industrial-based. Asterisks indicate level of significance at the * $-.10, * *-.05$ and $* * *$ - .01 level. Log-likelihoods are 273.500 and 275.824 respectively. Restricted slopes log-likelihoods are 677.886 and 677.886 respectively. Likelihood test statistics are 404.386 and 402.062 respectively. McFadden $\mathrm{R}^{2}$ is 0.597 and 0.593 respectively.

The estimated models are highly significant, with likelihood ratio tests of the hypothesis that all of the slope coefficients are zero rejected at the .01 level using the chi-square statistic. The results also appear sensible in terms of both the precision of the estimates and the signs on the coefficients. To detect possible sources of multicollinearity, 'variance inflation factors' (VIF) are calculated using auxiliary regressions to obtain the $\mathrm{R}^{2}$ for each independent variable when regressed on the remaining independent variables. As a rule of thumb, if the VIF of an independent variable exceeds 10, multicollinearity may be a problem (Kennedy, 1998). The highest VIFs are for AST (1.627), NIL (3.308) and TEX (3.404). These suggest that multicollinearity, while present, is not significant.

To start with, in the case of the probability of a credit union acquiring another during the sample period, the coefficients relating to managerial ability (PTE), earnings (NIL), asset size 
(ASS) and similarity in associational bond (SME) are significant and conform to the hypothesised sign. The results indicate that the larger (AST), more profitable (NIL) and more pure technically efficient (PTE) a credit union relative to the average credit union in the sample that maintains the status quo, the more likely it will acquire another credit union. Thompson (1997) likewise found that credit union size (by assets) was significant in determining takeover status in UK mutuals. These results are broadly comparable to the reduced model except that the levels of significance of the individual coefficients have generally increased.

Turning to the acquired credit unions, the estimated coefficients in both the full and reduced model indicate that credit unions that are smaller in terms of the size of total assets (AST), have a lower level of liquidity (LIQ) and are of the same associational bond (SME) as the acquiring credit union are more likely to be acquired, relative to the average credit union that is neither acquired nor acquires another. The fact that pure technical efficiency, as a proxy for managerial ability, is insignificant, accords with Brown et al. (1999, p. 15) who concluded on the basis of univariate statistics that 'exiting' credit unions “...were as efficient as the industry as a whole but included a number of small credit unions”. The major difference between the full and reduced model for acquired credit unions is that the ratio of provision for doubtful debts expense to total loans (PRD) is significant and negative suggesting that credit unions with a highly risky asset portfolio are less likely to be acquired, relative to a credit union that maintains the status quo. These results have important implications for the Australian credit union industry, especially in regards to efficiency. For example, since acquiring credit unions have higher efficiency on average than the acquired, the industry should become more efficient as a whole through M\&A activity. However, this is based on the assumption that the efficiency of the acquired credit union is raised to the level of the acquiring credit union.

Finally, the ability of the full and reduced models to accurately predict M\&A outcomes in credit unions is examined. Table 4 provides the predicted results for each different model. Of the forty acquiring credit unions in the sample, the full model predicted 24 cases $(60.0 \%)$ correctly, and incorrectly identified 4 cases (10.0\%) as acquired credit unions and 24 cases (30\%) as neither acquiring nor acquired credit unions. In terms of acquired credit unions, the full model correctly predicted 22 cases (50.0\%), and incorrectly identified 22 cases (50.0\%) as either acquiring credit unions or neither acquired nor acquiring credit unions. Lastly, of the 833 non-acquiring/acquired credit unions, the full model correctly identified all (100.0\%) as 
neither acquiring nor acquired credit unions. Overall, the full specification correctly identified 879 cases (95.9\%) in terms of the three possible M\&A outcomes. These results are broadly comparable to the number and percentage of correct predictions for the reduced model. The main difference is that the reduced model correctly identified slightly more cases as acquiring credit unions (62.5\%) and slightly less as acquired credit unions (47.7\%). The number and percentage correct of neither acquired nor acquiring credit unions was unchanged.

Table 4

Prediction success table

\begin{tabular}{clrcrrr}
\hline \multicolumn{1}{c}{ M\&A status } & Observed & $\begin{array}{c}\text { Predicted } \\
\text { Acquirin } \\
\text { g credit } \\
\text { unions }\end{array}$ & $\begin{array}{c}\text { Acquired } \\
\text { credit } \\
\text { unions }\end{array}$ & $\begin{array}{c}\text { All other } \\
\text { credit } \\
\text { unions }\end{array}$ & $\begin{array}{c}\text { Percentage } \\
\text { correct }\end{array}$ \\
\hline \multirow{5}{*}{ Full model } & Acquiring credit unions & 40 & 24 & 4 & 12 & 60.0 \\
& Acquired credit unions & 44 & 5 & 22 & 17 & 50.0 \\
& All other credit unions & 833 & 0 & 0 & 833 & 100.0 \\
& Total credit unions & 917 & 29 & 26 & 862 & 95.9 \\
\hline \multirow{3}{*}{ Reduced } & Acquiring credit unions & 40 & 25 & 3 & 12 & 62.5 \\
model & Acquired credit unions & 44 & 6 & 21 & 17 & 47.7 \\
& All other credit unions & 833 & 0 & 0 & 833 & 100.0 \\
& Total credit unions & 917 & 31 & 24 & 862 & 95.9 \\
\hline
\end{tabular}

These findings would initially suggest that either model might be more useful in identifying non-acquiring and non-acquired credit unions than credit unions engaging in M\&A activity. However, the predicted outcomes of both models offer a substantial relative improvement when comparisons are made with a constant probability model. Observations in the constant probability results are classified using the predicted probability given by the sample proportion of acquired, acquiring and non-acquired/non-acquiring credit unions. These probabilities, which are constant across credit unions, are therefore values computed from estimating a model that includes only an intercept term. For instance, of the 917 cases shown in Table 4, 40 are acquiring credit unions, 44 are acquired credit unions and 833 are neither acquired nor acquiring credit unions. The absolute gain is the percentage change of correct predictions of the estimated models over the percentage of correct predictions in the constant probability model. The relative gain is the absolute gain as a percentage of the incorrect predictions in the constant probability model. These provide an additional measure of the predictive ability of the estimated models.

For example, of the total 917 cases in the analysis, and using the sample proportions of cases, the constant probability model correctly predicts only 4.4 percent of acquiring cases, 4.8 percent of acquired cases and 90.8 percent of all other cases and thus incorrectly predicts 
95.6 percent of acquiring cases, 95.2 percent of acquired cases and 9.2 percent of all other cases. The full model alone thus represents a 55.6 percent absolute increase and a 58.1 relative increase over the constant probability model for acquiring cases, a 45.2 percent absolute and 47.5 percent relative increase for acquired cases, and a 9.2 percent absolute and 100.0 percent relative increase over all other cases. This indicates that the models employed are very useful for predicting credit union M\&A activity. Of course, these results are qualified in the sense that the ability of the model to categorise credit unions is conducted using insample data, whereas out-of-sample data (if available) would provide a more accurate and less biased indicator of predictive ability.

\section{Concluding remarks}

The present study uses a multinomial logit model to investigate the influence of financial, managerial and regulatory factors on the probability of a credit union acquiring or being acquired during the period 1992/93 to 1994/95. The current paper extends empirical work in this area in at least two ways. First, and as far as the author is aware, it represents the first attempt to test these purported factors in the Australian institutional milieu. This is quite apart from the fact that very few studies have examined the M\&A process of financial mutuals in general. Second, the paper incorporates nonparametric measures of pure technical and scale efficiency as factors in the M\&A process. This allows a more thorough examination of the role of managerial ability and optimal scale size in M\&A activity.

The study has identified several significant influences on M\&A activity in Australian credit unions. These include measures of financial performance, such as asset size, asset management and liquidity, and regulatory factors, including affinity of associational bond. The results also indicate that managerial ability, as proxied by nonparametric measures of pure technical efficiency, is an important influence on M\&A in credit unions, at least as far as acquiring credit unions are concerned. This is a matter of some importance to regulators in Australia. The suggestion is that M\&A activity could potentiality increase the efficiency of

the industry as a whole assuming the efficiency of the acquired credit union is raised to that of the acquiring credit union. If this is the case, then regulators interested in industry wide efficiency gains could assist this process by, say, matching prospective acquiring (more efficient) credit unions with suitable (less efficient) acquisitions. Other possible policy changes by regulators could include the provision of advisory services to credit unions 
regarding M\&A procedure and assisting acquiring credit unions to quickly transfer more efficient practices to operations that have been acquired. The ability of these models to accurately predict M\&A outcomes in credit unions was also examined. Of the acquiring credit unions in the sample, the full model predicted 60 percent of cases correctly, 50 percent of acquired cases correctly, and correctly identified all of the credit unions that neither acquired nor were acquired. This suggests that relatively parsimonious models can provide accurate predictions of M\&A activity, at least in regards to financial mutuals.

There are at least four ways in which this research may be extended. First, it would be useful to extend the methodology employed in the current study to measure post-merger efficiency. This would provide more direct evidence as to whether mergers are beneficial to the process of efficiency improvement in the banking system. A second extension would be to more rigorously define the extant posited determinants of M\&A activity, and extend the set of explanatory variables within the confines of the available data. For example, the data collected by the Australian Prudential Regulation Authority (APRA) also contains information relating to the number of members, branches and agencies. These may serve to identify whether M\&A are undertaken for the purpose of acquiring distribution networks and/or membership. Finally, similar techniques to the present study could be used to analyse the determinants of M\&A activity in related industry sectors, such as building societies, life insurance companies and commercial banks. This may serve to highlight additional issues of concern to policy-makers and other interested parties.

\section{Acknowledgements}

The author would like to thank participants at the $28^{\text {th }}$ Annual Conference of Economists, La Trobe University, seminar participants at the University of Southern Queensland, and two anonymous referees for helpful comments on an earlier version of this paper. The assistance of the Australian Prudential Regulation Authority (APRA) in providing the requisite data and the financial support of an Australian Research Council (ARC) grant is also gratefully acknowledged.

\section{References}

Banker RD, Charnes A, Cooper WW. Some models for estimating technical and scale inefficiencies in data envelopment analysis. Mgt Sci 1984;30(9):1078-1092.

Berg AA, Førsund FR, Hjalmarsson L, Suominen M. Banking efficiency in the Nordic countries. J Bank \& Fin 1993;17(2-3):371-388.

Berger AN, Demsetz RS and Strahan PE. The consolidation of the financial services industry: causes, consequences and implications for the future. J Bank \& Fin. 1999;23(2-4):135-194. 
Berger AN, Humphrey DB. Efficiency of financial institutions: International survey and directions for future research. Eur J Oper Res. 1997;98(2): 175-212.

Berger AN, Hunter WC, Timme SG. The efficiency of financial institutions: A review and preview of research past, present, and future. J Bank \& Fin 1993;17(2-3):221-249.

Brown R, Brown R, O’Connor I. Efficiency, bond of association and exit patterns in credit unions: Australian evidence. Ann Pub \& Coop Econ 1999;70(1):5-23.

Cebenoyan AS, Cooperman ES, Register CA, Hudgins SC. The relative efficiency of stock versus mutual S\&Ls: A stochastic frontier approach. J Fin Serv Res 1993;7(2):154-170.

Charnes A, Cooper WW, Rhodes E. Measuring the efficiency of decision making units. Eur J Oper Res 1978;2(6):429-444.

Coelli T, Rao DSP, Battese GE. An introduction to efficiency and productivity analysis. Boston: Kluwer, 1997.

Cooper WW, Seiford LM, Tone K. Data envelopment analysis: A comprehensive text with models, applications, references and DEA-solver software. Boston: Kluwer, 2000.

Cyree KB, Wansley JW, Boehm TP. Determinants of bank growth choice. J. Bank \& Fin 2000;24(5):709-734.

Davis K. Prudential regulation and cooperative financial institutions. Aust J Mgt 1994;8(1):31-46.

Drake L, Weyman-Jones TG. Productive and allocative inefficiencies in U.K. building societies: A comparison of non-parametric and stochastic frontier techniques. Manch Sch 1996;64(1):22-37.

Elyasiani E, Mehdian S, Rezvanian R. An empirical test of association between production and financial performance: The case of the commercial banking industry. App Fin Econ 1994;4(1):55-59.

Favero CA, Papi L. Technical efficiency and scale efficiency in the Italian banking sector: A non-parametric approach. App Econ 1995;27(4):385-395.

Fried HO, Lovell CAK, Turner JA. An analysis of the performance of university-affiliated credit unions. Comp Oper Res 1996;23(4):375-384.

Fried HO, Lovell CAK, Vanden Eekaut P. Evaluating the performance of US credit unions. J Bank \& Fin. 1993:17(2-3): 251-265.

Garden KE, Ralston DE. The x-efficiency and allocative efficiency effects of credit union mergers. J Int Fin Mkts, Inst Mny 1999;9(3):285-301

Grabowski R, Mathur I, Rangan N. The role of takeovers in increasing efficiency. Mgl Decis Econ 1995;16(3):211-223.

Grabowski R, Rangan N, Rezvanian R. Organisational forms in banking: An empirical investigation of cost efficiency. J Bank \& Fin 1993;17(2-3):531-538.

Kennedy P. A Guide to Econometrics. Blackwell: Oxford, 1998.

Miller SM, Noulas AG. The technical efficiency of large bank production. J Bank \& Fin 1996;20(1):495-509.

O’Brien KP. Thrift institutions: Building societies, credit unions and friendly societies, in The Australian Financial System, MK Lewis, RH Wallace, eds., Longman Cheshire, Melbourne. 1993, pp. 83-135.

Piesse J, Townsend R. The measurement of productive efficiency in UK building societies. App Fin Econ 1995; 5(2):397-407.

Shaffer S. Can megamergers improve bank efficiency? J Bank \& Fin 1993; 17(2-3):423-436.

Thompson S. Take-over activity among financial mutuals: An analysis of target characteristics. J Bank \& Fin 1997;21(1):37-53.

Westley GD, Shaffer S. Credit union policies and performance in Latin America. J Bank \& Fin 1999;23(9):1303-1329.

Worthington AC. Cost efficiency in Australian non-bank financial institutions: A non-parametric approach. Acc \& Fin. 2000;40(1): 75-97.

Worthington AC. Measuring technical efficiency in Australian credit unions. Manch Sch 1999;67(2):231-248.

Worthington AC. Testing the association between production and financial performance: Evidence from a notfor-profit cooperative setting. Ann Pub \& Coop Econ 1998;69(1):67-84. 